\title{
Aplikasi Diagnosis Kelainan Refraksi Mata Dan Tips Perawatan Mata Dengan Metode Forward Chaining Berbasis Web
} (Studi Kasus Rosya Optikal)

\author{
Sayyidah Fathimah ${ }^{1}$, Suryatiningsih ${ }^{2}$, Siska Komala Sari ${ }^{3}$ \\ ${ }^{1,2,3}$ Program Studi D3 Manajemen Informatika, Fakultas Ilmu Terapan, Universitas Telkom \\ $1,2,3 \mathrm{Jl}$. Telekomunikasi, Dayeuh Kolot Kab. Bandung 40257, Indonesia \\ ${ }^{1}$ sayyidahfathimah@students.telkomuniversity.ac.id, ${ }^{2}$ suryatiningsih@tass.telkomuniversity.ac.id, \\ ${ }^{3}$ siska@tass.telkomuniversity.ac.id
}

\begin{abstract}
Abstrak - Diagnosis merupakan penentuan jenis-jenis penyakit berdasarkan penelitian sesuai dengan gejalagejala yang dialami. Gejala gangguan penglihatan yang sering dialami adalah rabun. Rabun dapat berupa rabun melihat benda jauh, rabun melihat benda pada jarak dekat dan lain-lain. Semua jenis rabun mata pada intinya merupakan gangguan memfokuskan bayangan benda yang dilihat atau kelainan refraksi (Ametropia). Untuk mengetahui kelainan refraksi pada mata di Rosya Optikal masih menggunakan cara manual yaitu dengan pasien datang ke Rosya Optikal melakukan pendaftaran, pemeriksaan mata, refraksionis optisien mendiagnosis dan memberikan hasil diagnosisnya, memberikan tips perawatan mata beserta resep pembuatan kacamata diberikan kepada pasien. Cara ini merupakan hal yang biasa dilakukan, namun tidak semua orang mempunyai waktu dan kesempatan untuk melakukan pemeriksaan mata dikarenakan kesibukan pekerjaan yang harus dilakukan. Melihat alasan diatas, maka diperlukan pembuatan alat bantu untuk diagnosis kelainan refraksi pada mata dan memberikan tips perawatan mata. Pembuatan Aplikasi Diagnosis Kelainan Refraksi Pada Mata dan Tips Perawatan Mata dengan Metode Forward Chaining yaitu metode pencarian atau teknik pelacakan ke depan yang dimulai dengan informasi yang ada dan penggabungan rule untuk menghasilkan suatu kesimpulan atau tujuan. Pengujian aplikasi menggunakan black box testing yang dilakukan hanya mengamati hasil eksekusi melalui data uji dan memeriksa fungsional dari perangkat lunak.Dengan adanya alat bantu ini, pengguna dapat mengetahui kelainan mata yang dialami, mendapatkan tips perawatan mata sehingga dapat merawat dan mencegah penyakit mata yang berkelanjutan dan solusi jenis kacamata jika diperlukan.
\end{abstract}

Kata kunci - Diagnosis, Kelainan Refraksi, Metode Forward Chaining

\begin{abstract}
The diagnosis is the process of determining which disease on condition explains a person's symptoms sign. Disorder symptoms often experienced is myopic vision. Shortsighted could include shortsighted see distant objects, myopic see objects at close range and others. All kinds of the myopic focus on the point is a disorder of the shadow of objects seen or an abnormality of the refraction ( ametropia ). To know in the eye in an abnormality of the refraction rosya optically still use manual way that is by the patient came to registration rosya optically do, eye examinations, refraksionis diagnosisnya optisien diagnose and provide the results, give the tips of the eye care and prescription making glasses given to patients. This way it is usually done, but not all men have the time and opportunity to conduct the examination of the eye because of the activities of work to be done .See reason above, then required making the tools for diagnosis abnormality refraction on the eye and give tips care eyes. The manufacture of diagnosis an abnormality of the refraction of application to the eyes and the eyes with a method of tips care forward chaining that is a method or technique of tracking search forward that began with the existing information and amalgamation rule to produce a conclusion or purpose. The testing of the aplication using the black box of testing performed only observe execution through the results of the test data and check functional from software. By the presence of the tools, users know abnormalities of the eyes experienced, receive tips care the eye that could take care of and prevent diseases of the eye sustainable and types of glasses solution if necessary.
\end{abstract}

Keywords - Diagnostic, An abnormality of refraction, Rosya Optical, A method of chaining forward

\section{PENDAHULUAN}

Mata adalah salah satu dari indera tubuh manusia yang berfungsi untuk penglihatan. Meskipun fungsinya bagi kehidupan manusia sangat penting, namun sering kali kurang mendapat perhatian, sehingga banyak penyakit yang menyerang mata tidak diobati dengan baik dan menyebabkan gangguan penglihatan sampai kebutaan. Diagnosis merupakan 
penentuan jenis-jenis penyakit berdasarkan penelitian sesuai dengan gejala-gejala yang dialami. gejala gangguan penglihatan yang sering dialami adalah rabun.

Rabun dapat berupa rabun melihat benda jauh, rabun melihat benda pada jarak dekat, rabun ketika sedang membaca yang biasanya dialami mereka yang berusia di atas 40 tahun atau campuran dari rabun melihat benda jauh dan rabun ketika sedang membaca. Semua jenis rabun mata pada intinya merupakan gangguan memfokuskan bayangan benda yang dilihat atau kelainan refraksi (Ametropia). Untuk mengetahui kelainan refraksi pada mata di Rosya Optikal masih menggunakan cara manual yaitu dengan pasien datang ke Rosya Optikal melakukan pendaftaran, pemeriksaan mata, refraksionis optisien mendiagnosis dan memberikan hasil diagnosisnya, memberikan tips perawatan mata beserta resep pembuatan kacamata diberikan kepada pasien. Cara ini merupakan hal yang biasa dilakukan, namun tidak semua orang mempunyai waktu dan kesempatan untuk melakukan pemeriksaan mata dikarenakan kesibukan pekerjaan yang harus dilakukan.

Melihat alasan diatas, maka diperlukan pembuatan alat bantu untuk diagnosis kelainan refraksi pada mata dan memberikan tips perawatan mata. Dengan adanya alat bantu, pengguna mengetahui kelainan mata yang dialami, mendapatkan tips perawatan mata sehingga dapat merawat dan mencegah penyakit mata yang berkelanjutan dan solusi jenis kacamata jika diperlukan.

Dari penjelasan diatas maka tujuan proyek akhir ini membuat.

1. Aplikasi yang mampu menangani pemeriksaan kelainan refraksi pada mata pasien.

2. Aplikasi yang mampu mendiagnosis dan mengetahui hasil diagnosis kelainan refraksi pada mata pasien dengan menggunakan metode forward chaining.

3. Aplikasi yang mampu mengetahui tips perawatan mata yang sesuai dengan kelainan mata yang dialami pasien.

4. Aplikasi yang mampu mengetahui solusi jenis lensa yang sesuai dengan kelainan mata yang dialami pasien.

\section{TINJAUAN PUSTAKA}

\section{A. Sequence Diagram}

Sequence diagram adalah diagram interaksi yang menekankan pada pengiriman pesan (message) dalam suatu waktu tertentu [2].

\section{B. Kelainan Refraksi pada Mata}

Kelainan refraksi adalah keadaan bayangan tegas tidak dibentuk pada retina, dimana terjadi ketidakseimbangan sistem penglihatan pada mata sehingga menghasilkan bayangan yang kabur. Sinar tidak dibiaskan tepat pada retina, tetapi dapat di depan atau di belakang retina dan/ atau tidak terletak pada satu titik fokus. Kelainan refraksi dapat diakibatkan terjadinya kelainan kelengkungan kornea dan lensa, perubahan indeks bias, dan kelainan panjang sumbu bola mata.

Macam-macam kelainan Refraksi [3]:

1. Mata Myopia

Myopi / Rabun Jauh terjadi jika bola mata terlalu panjang dari depan ke belakang, dan berkas cahaya menjadi terfokus di depan retina dan mengakibatkan penglihatan kabur atau buram.

2. Mata Hipermetropi

Hipermetropi / Rabun Dekat terjadi jika bola mata lebih kecil dari normal atau lensa tidak bisa berakomodasi dengan baik, hal ini berakibat objek yang terlihat difokuskan ke belakang retina dan penglihatan menjadi kabur.

3. Mata Asigmatisme

Astigmatisme / Mata Silindris terjadi karena bervariasinya daya refraksi kornea atau lensa karena kelainan bentuk permukaannya sehingga sinar yang jatuh pada dua titik di depan retina.

\section{Mata Presbiopi}

Presbiopi / Mata Tua terjadi Gangguan akomodasi pada usia lanjut yang dapat terjadi akibat kelemahan otot akomodasi, lensa mata tidak kenyal atau berkurang elastisitasnya akibat sclerosis lensa.

\section{Mata Katarak}

Katarak / Mata Buram terjadi karena Cairan dalam lensa keruh, lensa mata kelihatan putih dan cahaya tidak dapat menembusnya.

\section{Metode Forward Chaining}

Metode Forward Chaining adalah metode pencarian atau teknik pelacakan ke depan yang dimulai dengan informasi yang ada dan penggabungan rule untuk menghasilkan suatu kesimpulan atau tujuan. Pelacakan maju ini sangat baik jika bekerja dengan permasalahan yang dimulai dengan rekaman informasi awal dan ingin dicapai penyelesaian akhir, karena seluruh proses akan dikerjakan secara berurutan maju. Berikut adalah diagram Forward Chaining secara umum untuk menghasilkan sebuah goal Forward chaining merupakan grup dari multiple inferensi yang melakukan pencarian dari suatu masalah kepada solusinya. Forward chaining adalah data-driven karena inferensi dimulai dengan informasi yang tersedia dan baru konklusi diperoleh. Metode forward 
chaining adalah metode dimana penelusuran di mulai dari mengambil fakta-fakta terlebih dahulu baru kemudian digunakan untuk menarik simpulan. Dalam hal ini gejala digunakan sebagai fakta, setelah semua data gejala terpenuhi dapat digunakan untuk menarik simpulan mengenai suatu penyakit. Adapun basis pengetahuan yang digunakan adalah penalaran berbasis aturan (Rule-Based Reasoning) [4].

\section{D. $P H P$}

PHP (Hypertext Preeprocesor) ini merupakan bahasa yang hanya dapat berjalan pada server yang hasilnya dapat ditampilkan pada klien. Interpreter PHP dalam mengeksekusi kode PHP pada sisi server (disebut server-side) berbeda dengan mesin maya Java yang mengeksekusi program pada sisi klien (client-side). PHP merupakan bahasa standar yang digunakan dalam dunia website. PHP adalah bahasa program yang berbentuk script yang diletakan didalam server web [5].

\section{E. CSS}

CSS atau Cascading Style Sheets adalah suatu fasilitas untuk mempermudah pemeliharaan sebuah halaman web, dengan menggunakan CSS sebuah halaman web dapat diubah tampilannya tanpa harus mengubah dokumen HTML-nya [5].

\section{F. $H T M L$}

HTML atau Hypertext Markup Language adalah suatu format data yang digunakan untuk membuat dokumen hypertext (teks pada computer yang memungkinkan user saling mengirimkan informasi(request-respon)). Dokumen HTML harus disimpan dengan ekstensi .htm atau .html. HTML memiliki tag-tag yang telah didefinisikan untuk membuat halaman web. Penulisan tag-tag HTML dapat menggunakan huruf besar atau huruf kecil, karena tidak case sensitive (membedakan huruf besar dan huruf kecil memiliki maksud berbeda) [5].

\section{G. Diagnosis}

Menurut Thorndike dan Hagen yang dikutip oleh Abin Syamsudin Makmun (2007 : 307) diagnosis dapat diartikan sebagai [6]:

1. Upaya atau proses menemukan kelemahan atau penyakit apa yang dialami seseorang dengan melalui pengujian dan studi yang sesama mengenai gejala-gejalanya.

2. Studi yang seksama terhadap fakta sesuatu hal untuk menemukan karakteristik atau kesalahankesalahan dan sebagainya yang esensial.

3. Keputusan yang dicapai setelah dilakukan studi yang seksama atas gejalagejala atau fakta tentang suatu hal.

\section{H. $M y S Q L$}

Data adalah bagian penting dari pemograman modern sehingga keseluruhan bahasa program menyediakan fungsi untuk mengakses database. Standar utama untuk bahasa database adalah Structured Query Language (SQL). SQL distandarisasi sebagai bahasa untuk menciptakan database, menyimpan informasi ke dalam database dan mendapatkan kembali informasi darinya. Aplikasi khusus dan lingkungan pemrograman mengkhususkan diri untuk menginterprestasikan data SQL.

Seorang programmer akam mulai dengan menciptakan suatu struktur data di dalam SQL dan kemudian menulis suatu program dalam bahasa (PHP) untuk mengakses data tersebut. Program PHP kemudian bisa memformulasikan permintaan atau memperbarui data tersebut, yang dilewatkan ke interpreter SQL. Banyak Relational Database Management System (RDBMS) yang tersedia, tetapi MySQL khususnya sangat cocok untuk bekerja sama dengan PHP. Bagaimanapun, konsep dasar SQL tetap sama apapun jenis database yang digunakan [7].

\section{Entity Relationship Diagram}

Entity Relationship Diagram (ERD) merupakan pemodelan basisdata yang paling sering gunakan dalam analisis basisdata. Entity Relationship Diagram (ERD) dikembangkan berdasarkan teori himpunan dalam bidang metematika. Entity Relationship Diagram (ERD) digunakan untuk pemodelan basis data relasional [8].

1. Entity

Entity adalah suatu obyek yang dapat diidentifikasi dalam lingkungan pemakai, sesuatu yang penting bagi pemakai dalam konteks sistem yang akan dibuat.

2. Atribut

Atribut berfungsi untuk mendeskripsikan karakter entity.

3. Hubungan

Entity dapat berhubungan satu sama lain. Hubungan ini dinamakan relationships (relasi).

\section{J. Flowmap}

FlowMap merupakan alat bantu konvensional, disebut juga Mapping flow atau Process Function chart atau Diagram aliran dokumen atau Diagram Sistem Prosedur Kerja atau Paperwork Flowchart. Flowmap Merupakan diagram yang menggambarkan aliran dokumen pada suatu prosedur kerja di organisasi dan memperlihatkan diagram alir yang menunjukkan arus dari dokumen, aliran data fisik, entitas-entitas sistem informasi dan kegiatan operasi yang berhubungan dengan sistem informasi. Penggambaran biasanya diawali dengan mangamati dokumen apa yang menjadi media data atau 
informasi. Selanjutnya ditelusuri bagaimana dokumen tersebut terbentuk, ke bagian atau entitas mana dokumen tersebut mengalir, perubahan apa yang terjadi pada dokumen tersebut, proses apa yang terjadi terhadap dokumen tersebut, dan seterusnya [9].

\section{K. Class diagram}

Diagram kelas atau class diagram menggambarkan struktur dari segi pendefinisian kelas-kelas yang akan dibuat untuk membangun sistem. Kelas memiliki apa yang disebut atribut dan metode atau operasi [2].

1. Atribut merupakan variabel-variabel yang dimiliki oleh suatu kelas.

2. Operasi atau metode adalah fungsi-fungsi yang dimiliki oleh suatu kelas.

\section{Activity Diagram}

Diagram aktivitas menggambarkan workflow (aliran kerja) atau aktivitas dari sebuah sistem atau proses bisnis atau menu yang ada pada perangkat lunak. Yang perlu diperhatikan disini adalah bahwa diagram aktivitas menggambarkan aktivitas sistem bukan apa yang dilakukan aktor, jadi aktivitas yang dapat dilakukan oleh sistem [2].

\section{Aplikasi Web}

Aplikasi Web adalah sutau aplikasi yang diakses menggunakan browser melalui suatu jaringan seperti internet atau intranet. Dalam hal ini terdapat 3 komponen untuk menjalankan aplikasi web, yaitu web client, web server, dan jaringan. Aplikasi web merupakan aplikasi yang menggunakan arsitektur client-server yaitu dimana program client (web browser) terhubung pada sebuah server agar dapat mengakses sumber daya yang disediakan oleh browser [10].

\section{N. Black Box Testing}

Pengujian Black Box Testing berfokus pada persyaratan fungsional perangkat lunak. Dengan demikian, pengujian balck box memungkinkan perekayasa perangkat lunak mendapatkan serangkaian kondisi input yang sepenuhnya menggunakan semua persyaratan fungsional untuk suatu program. Pengujian black box bukan merupakan alternatif dari teknik white box, tetapi merupakan pendekatan komplementer yang kemungkinan besar mampu menguap kelas kesalahan daripada metode white box. Pengujian black box berusaha menemukan kesalahan dalam kategori sebagai berikut [1]:

1. Fungsi-fungsi yang tidak benar atau salah.

2. Kesalahan interface.

3. Kesalahan dalam struktur data atau database eksternal.

4. Kesalahan kinerja.

5. Instalasi dan kesalahan terminasi.

\section{O. Use Case Diagram}

Use Case adalah salah satu diagram yang ada dalam UML (unifed Modeling Language). Use case atau diagram use case merupakan pemodelan untuk kelakuan (behavior) aplikasi perangkat lunak yang akan dibuat. Use case mendeskripsikan sebuah interaksi antara satu atau lebih aktor dengan aplikasi yang akan dibuat. Secara kasar, use case digunakan untuk mengetahui fungsi/proses apa saja yang ada didalam sebuah aplikasi dan siapa saja yang berhak menggunakan fungsi-fungsi/proses-proses itu. Syarat penamaan pada use case adalah nama didefinisikan sesimpel mungkin dan dapat dipahami. Ada dua hal utama pada use case yaitu pendefinisian apa yang disebut actor dan use case/proses.

1. Aktor merupakan orang,proses, atau aplikasi lain yang berinteraksi dengan aplikasi yang akan dibuat diluar aplikasi yang akan dibuat itu sendiri, jadi walaupun simbol dari actor adalah gambar orang, tapi aktor belum tentu merupakan orang.

2. Use case merupakan fungsi-fungsi/prosesproses yang disediakan aplikasi sebagai unit unit yang saling bertukar pesan / berinteraksi antar unit / proses atau aktor. [2]

\section{P. YII}

Yii merupakan gagasan dari pendirinya Qiang Xue yang memulai proyek Yii pada tanggal 1 Januari 2008. Berikut ini adalah pengertian dan kelebihan yii:

\section{Pengertian YII}

Yii adalah component based high performance PHP kerangka kerja untuk mengembangkan skala besar aplikasi Web. Yii ditulis dalam OOP dan dilengkapi dengan referensi kelas menyeluruh dan tutorial yang komprehensif. Dari MVC, DAO / ActiveRecord, widget, caching, RBAC hirarkis, layanan Web, untuk tema, I18N dan L10N. Yii menyediakan hampir semua fitur yang dibutuhkan oleh saat ini pengembangan aplikasi Web 2.0, menyediakan resuabilitas maksimum dalam pemrograman Web dan bisa mengakselerasi proses pengembangan secara signifikan. Nama Yii (dieja sebagai/i:/) singkatan dari easy, efficient dan extensible (mudah,efisie $n$, dan bisa diperluas). Untuk menjalankan aplikasi Web bertenaga-Yii, Anda memerlukan server Web yang mendukung PHP 5.1.0 atau lebih tinggi.Bagi para pengembang yang ingin menggunakan Yii, mengerti pemrograman terorientasi-obyek (OOP) akan sangat membantu, karena Yii murni kerangka kerja OOP [11].

2. Kelebihan YII YII memiliki kelebihan, antara lain : 
a. Yii adalah salah satu framework yang sangat ringan dan dilengkapi dengan solusi caching yang memuaskan.

b. Yii sangat cocok untuk pengembangan aplikasi dengan lalu lintas-tinggi, seperti portal, forum, sistem manajemen konten (CMS), sistem e-commerce, dll.

c. Yii didokumentasikan dengan jelas, efisien, dan kaya-fitur.

\section{METODOLOGI PENELITIAN}

Dalam pembuatan aplikasi ini digunakan metode Software Development Life Cycle (SDLC) dengan model waterfall kadang dinamakan siklus hidup klasik (classic life cycle), dimana hal ini menyiratkan pendekatan yang sistematis dan berurutan (sekuensial) pada pengembangan perangkat lunak, yang dimulai dengan spesifikasi kebutuhan pengguna dan berlanjut melalui tahapan-tahapan perencanaan (planning), pemodelan (modelling), konstruksi (construction), serta penyerahan sistem/perangkat lunak ke para pelanggan/pengguna (deployment) yang diakhiri dengan dukungan berkelanjutan pada perangkat lunak lengkap yang dihasilkan [1].

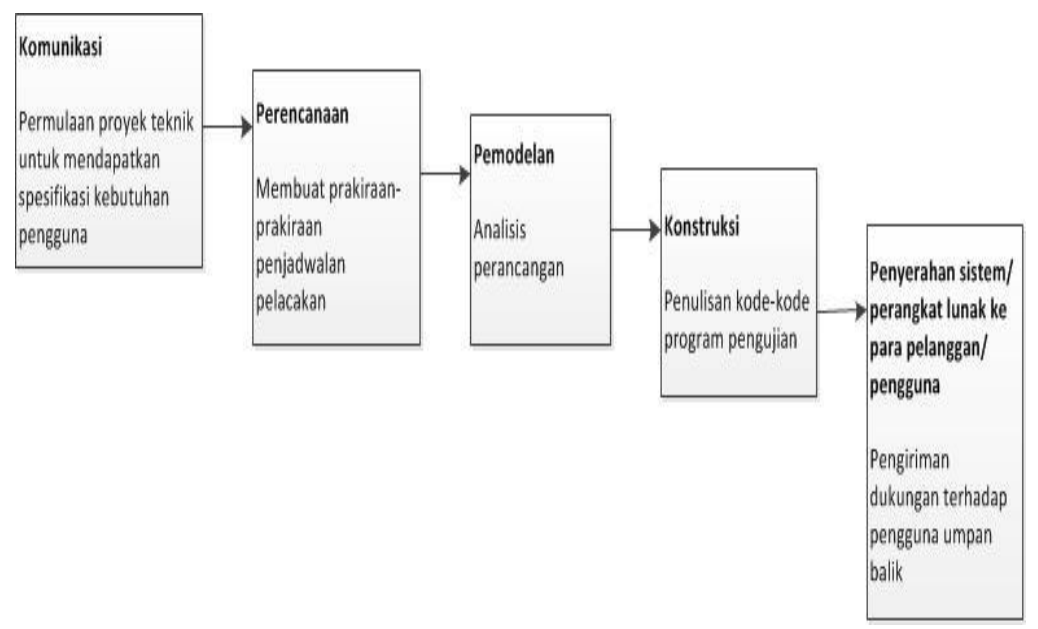

Gambar 1. Model Waterfall

Model waterfall melingkupi aktivitas-aktivitas sebagai berikut.

1. Komunikasi

Pada tahap ini dilakukan proses komunikasi sebagai permulaan proyek teknik untuk mendapatkan spesifikasi kebutuhan yang dibutuhkan oleh Rosya Optikal.

2. Perencanaan

Pada tahap ini dilakukan proses perencanaan kebutuhan data yang dimulai dari identifikasi masalah serta pengumpulan data melalui wawancara dengan refreksionis optisien untuk mendapatkan data sebagai acuan dalam Pembuatan Aplikasi Diagnosis Kelainan Refraksi Pada Mata dan Tips Perawatan Mata dengan Metode Forward Chaining pada Rosya Optikal.

3. Pemodelan

Dalam tahapan ini dilakukan pemodelan sistem yaitu pembuatan UML yang meliputi Flowmap sebagai rancang model proses bisnis kegiatan pemeriksaan dan diagnosis, Use Case Diagram sebagai rancang model interaksi pengguna dengan aplikasi dan Entity
Relational Diagram (ERD) sebagai rancang model basisdata serta pembuatan mockup desain interaksi pengguna sebagai rancang model user interface.

4. Konstruksi

Setelah tahap desain sistem selesai, maka dilakukan transformasi dari desain yang telah dirancang ke bahasa yang dikenal oleh komputer (coding) yaitu penulisan kode-kode program dengan menggunakan bahasa pemrograman $P H P$ dan framework Yii serta MySQL sebagai bahasa pemrograman basis data. Kemudian dilakukan pengujian dengan metode black box testing, yaitu melakukan pengujian terhadap masukan, proses dan keluaran aplikasi, hal ini bertujuan untuk memastikan semua fungsionalitas yang disusun bekerja dengan benar dan sesuai proses bisnis kegiatan pemeriksaan dan diagnosis.

5. Penyerahan Sistem

Pada tahap ini dilakukan penyerahan sistem atau perangkat lunak kepada Rosya Optikal. 
6. Dokumentasi

Setelah semua proses dilakukan dengan benar, maka dalam tahap ini dilakukan penulisan dokumentasi dari komunikasi, perencanaan, pemodelan, konstruksi, serta penyerahan sistem/perangkat lunak ke pada Rosya Optikal.

\section{HASIL DAN PEMBAHASAN}

\section{A. Metode Forward Chaining}

Berikut ini adalah penerapan metode forward chaining yang diterapkan pada aplikasi. Relasi aturan merupakan penentuan kelainan refraksi berdasarkan gejalanya. Tabel 1 merupakan tabel relasi gejala pada setiap kelainan refraksi, dapat menentukan aturan yang digunakan untuk kelainan refraksi.

Tabel 1. Relasi Aturan

\begin{tabular}{|c|c|c|c|c|c|c|c|}
\hline \multirow{2}{*}{ No } & \multirow{2}{*}{ Kode } & \multirow{2}{*}{ Gejala } & \multicolumn{5}{|c|}{$\begin{array}{l}\text { Kelainan } \\
\text { Refraksi }\end{array}$} \\
\hline & & & $\mathbf{1}$ & 2 & 3 & 4 & 5 \\
\hline 1 & G001 & Penglihatan buram & $*$ & $*$ & $*$ & $*$ & \\
\hline 2 & G002 & $\begin{array}{l}\text { Mata mudah tegang dan } \\
\text { lelah }\end{array}$ & $*$ & $*$ & $*$ & $*$ & \\
\hline 3 & G003 & Sakit kepala & $*$ & $*$ & $*$ & & $*$ \\
\hline 4 & G004 & $\begin{array}{l}\text { Benda terlihat kabur jika } \\
\text { jarak dekat, tetapi benda } \\
\text { terlihat jelas jika jarak } \\
\text { jauh }\end{array}$ & & $*$ & & * & \\
\hline 5 & G005 & $\begin{array}{l}\text { Kesulitan membaca } \\
\text { tulisan dengan cetakan } \\
\text { huruf yang halus / kecil }\end{array}$ & & & $*$ & $*$ & \\
\hline 6 & G006 & $\begin{array}{l}\text { Sudah berusia lebih dari } \\
40 \text { tahun }\end{array}$ & & & & * & $*$ \\
\hline 7 & G007 & $\begin{array}{l}\text { Benda terlihat kabur jika } \\
\text { jarak jauh, tetapi benda } \\
\text { terlihat jelas jika jarak } \\
\text { dekat }\end{array}$ & $*$ & & & & \\
\hline 8 & G008 & $\begin{array}{l}\text { Menyipitkan mata untuk } \\
\text { melihat objek jauh }\end{array}$ & $*$ & & & & \\
\hline 9 & G009 & Rabun pada malam hari & * & & & & \\
\hline 10 & G010 & $\begin{array}{l}\text { Menyipitkan mata untuk } \\
\text { melihat objek dekat }\end{array}$ & & $*$ & & & \\
\hline 11 & G011 & Masalah dalam membaca & & $*$ & & & \\
\hline 12 & G012 & $\begin{array}{l}\text { Suka memiringkan kepala } \\
\text { saat melihat obyek }\end{array}$ & & & $*$ & & \\
\hline 13 & G013 & $\begin{array}{l}\text { Penglihatan dekat dan } \\
\text { jauh kabur }\end{array}$ & & & $*$ & & \\
\hline 14 & G014 & $\begin{array}{l}\text { Tidak bisa melihat objek } \\
\text { jarak jauh maupun jarak } \\
\text { dekat }\end{array}$ & & & & $*$ & \\
\hline 15 & G015 & $\begin{array}{l}\text { Penglihatan tidak jelas, } \\
\text { seperti terdapat kabut } \\
\text { menghalangi objek. }\end{array}$ & & & & & $*$ \\
\hline 16 & G016 & $\begin{array}{l}\text { Lensa mata berubah } \\
\text { menjadi buram seperti } \\
\text { kaca susu }\end{array}$ & & & & & $*$ \\
\hline
\end{tabular}

\begin{tabular}{|c|c|c|c|c|c|c|c|}
\hline \multirow[t]{2}{*}{ No } & \multirow{2}{*}{ Kode } & \multirow{2}{*}{ Gejala } & \multicolumn{5}{|c|}{$\begin{array}{l}\text { Kelainan } \\
\text { Refraksi }\end{array}$} \\
\hline & & & 1 & 2 & 3 & 4 & 5 \\
\hline 17 & G017 & $\begin{array}{l}\text { Mata menjadi sensitif } \\
\text { pada cahaya }\end{array}$ & & & & & $*$ \\
\hline 18 & G018 & $\begin{array}{l}\text { Melihat objek menjadi } \\
\text { ganda dengan } \\
\text { menggunakan } 1 \text { mata }\end{array}$ & & & & & $*$ \\
\hline
\end{tabular}

Keterangan: (1) Myopi; (2) Hipermetropi; (3) Astigmatisme; (4) Presbiopi; (5) Katarak

Tabel 2. Basis Pengetahuan

\begin{tabular}{ll}
\hline No & \multicolumn{1}{c}{ Aturan } \\
\hline & IF Penglihatan buram \\
& AND Mata mudah tegang dan lelah \\
& AND Sakit kepala
\end{tabular}

AND Benda terlihat kabur jika jarak jauh, tetapi benda 1 terlihat jelas jika jarak dekat

AND Menyipitkan mata untuk melihat objek jauh

AND Rabun pada malam hari

THEN Myopi / Rabun Jauh

IF Penglihatan buram

AND Mata mudah tegang dan lelah

AND Sakit kepala

AND Benda terlihat kabur jika jarak dekat, tetapi benda terlihat jelas jika jarak jauh

AND Menyipitkan mata untuk melihat objek dekat

AND Masalah dalam membaca

THEN Hipermetropi / rabun dekat

IF Penglihatan buram

AND Mata mudah tegang dan lelah

AND Sakit kepala

AND Kesulitan membaca tulisan dengan cetakan huruf yang halus/Kecil

AND Suka memiringkan kepala saat melihat obyek

AND Penglihatan dekat dan jauh kabur

THEN Astigmatisme / mata silindris

IF Penglihatan buram

AND Mata mudah tegang dan lelah

AND Benda terlihat kabur jika jarak dekat, tetapi benda terlihat jelas jika jarak jauh

4 AND Kesulitan membaca tulisan dengan cetakan huruf yang halus / kecil

AND Sudah berusia lebih dari 40 tahun

AND Tidak bisa melihat objek jarak jauh maupun jarak dekat

THEN Presbiopi / mata tua 


\begin{tabular}{ll}
\hline No & \multicolumn{1}{c}{ Aturan } \\
\hline & IF sakit kepala \\
& AND Sudah berusia lebih dari 40 tahun \\
& AND Penglihatan tidak jelas, seperti terdapat kabut \\
& menghalangi objek. \\
& AND Lensa mata berubah menjadi buram seperti kaca \\
& susu \\
& AND Mata menjadi sensitive pada cahaya \\
& $\begin{array}{l}\text { AND Melihat objek menjadi ganda dengan } \\
\text { menggunakan 1 mata }\end{array}$ \\
& THEN Katarak / mata buram \\
\hline
\end{tabular}

\section{B. Flowmap}

Pada Gambar 2 menunjukkan flowmap proses pemeriksaan dan diagnosis pasien. Alurnya dimulai dari pasien membuka website dan menjawab semua pertanyaan yang ditampilkan, lalu jawaban akan disimpan dan data dicocokan dengan aturan pada Metode Forward Chaining yang telah didefinisikan pada Tabel 2. Hasil diagnosa ditampilkan di layar beserta tips dan solusi jenis lensa bagi yang mengalami kelainan pada matanya.

\section{Usecase Diagram}

Pada Gambar 3 menunjukkan use case diagram yang diusulkan.

\section{Diagram Class}

Pada Gambar 4 menunjukkan class diagram dari aplikasi diagnosis kelainan refraksi pada mata dan tips perawatan mata yang memiliki beberapa kelas yaitu class PageController, class AdminController dan class PakarController.

\section{E. Entity Relationship Diagram}

Pada Gambar 5 ditunjukkan entity relationship diagram berdasarkan datastore.

\section{F. Skema Relasi}

Adapun skema relasi untuk entity relationship diagram diatas adalah seperti yang ditunjukkan pada Gambar 6.

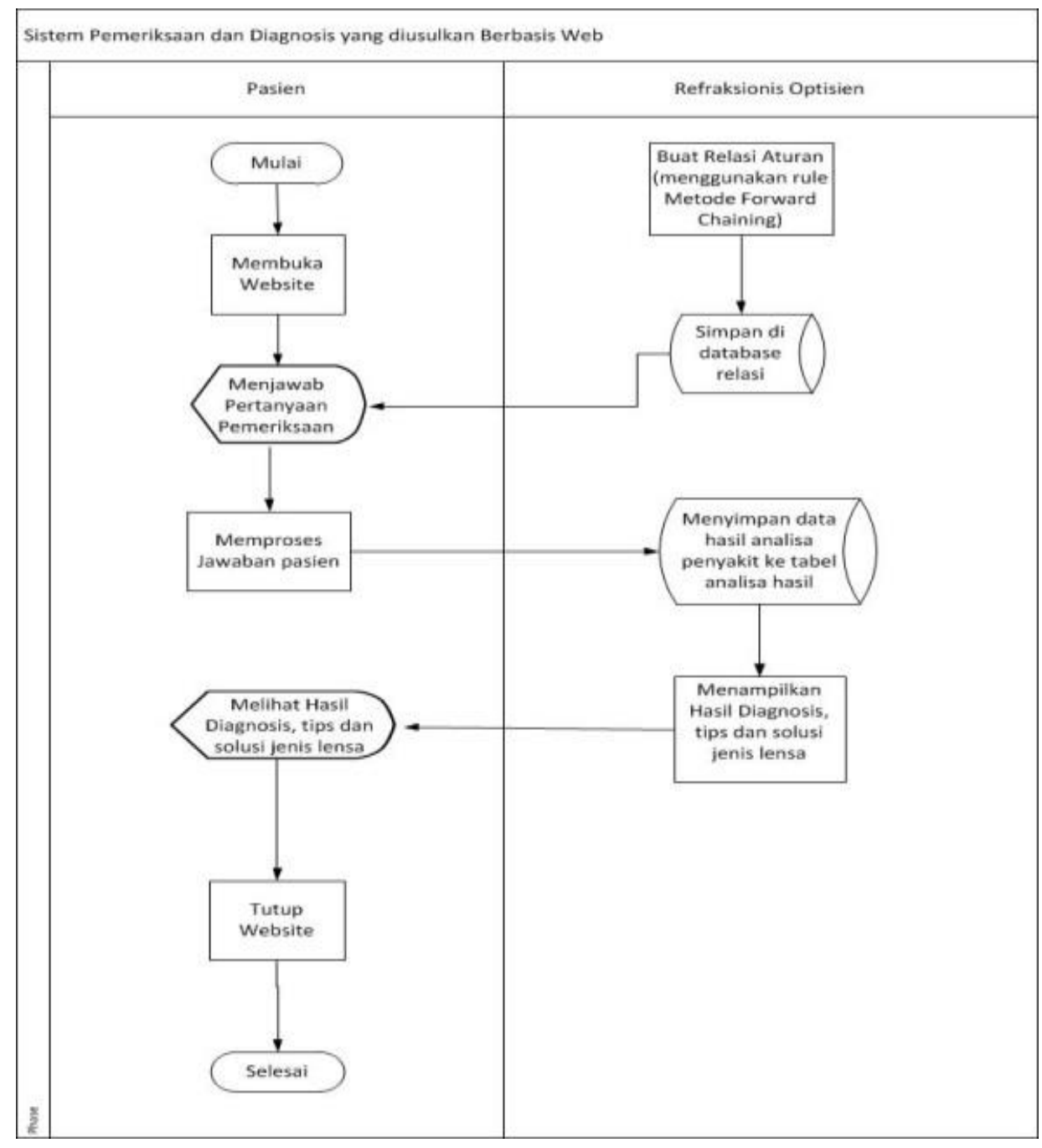

Gambar 2. Flowmap Usulan 


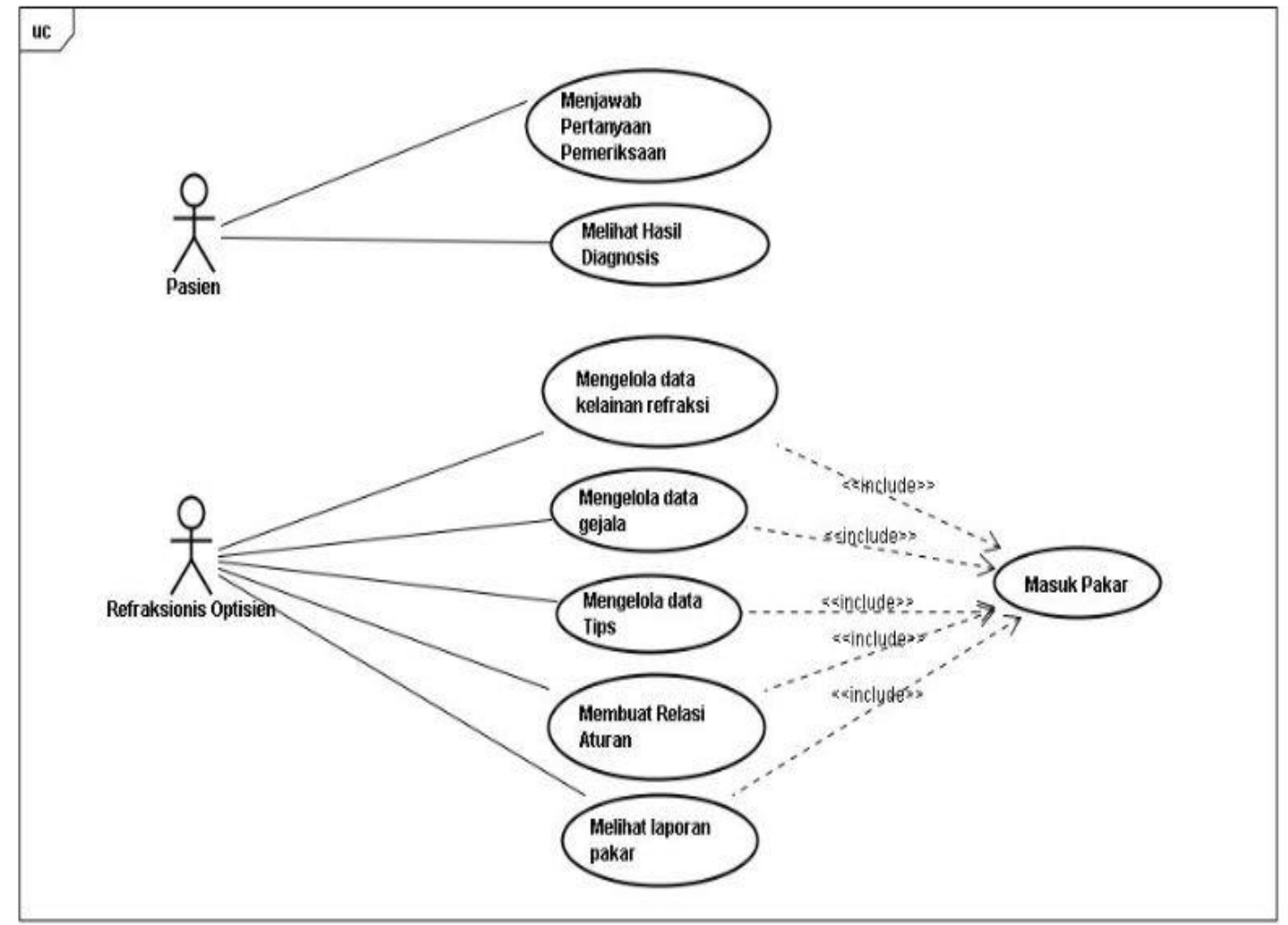

Gambar 3. Usecase

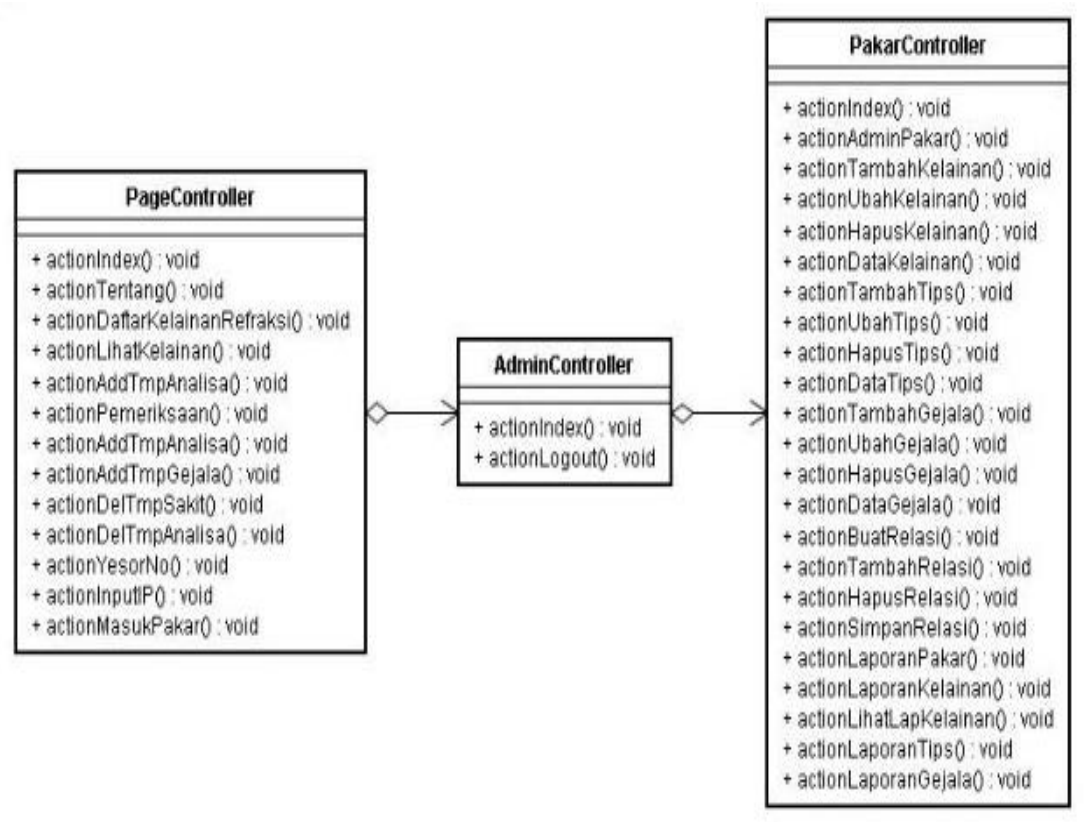

Gambar 4. Diagram Class 


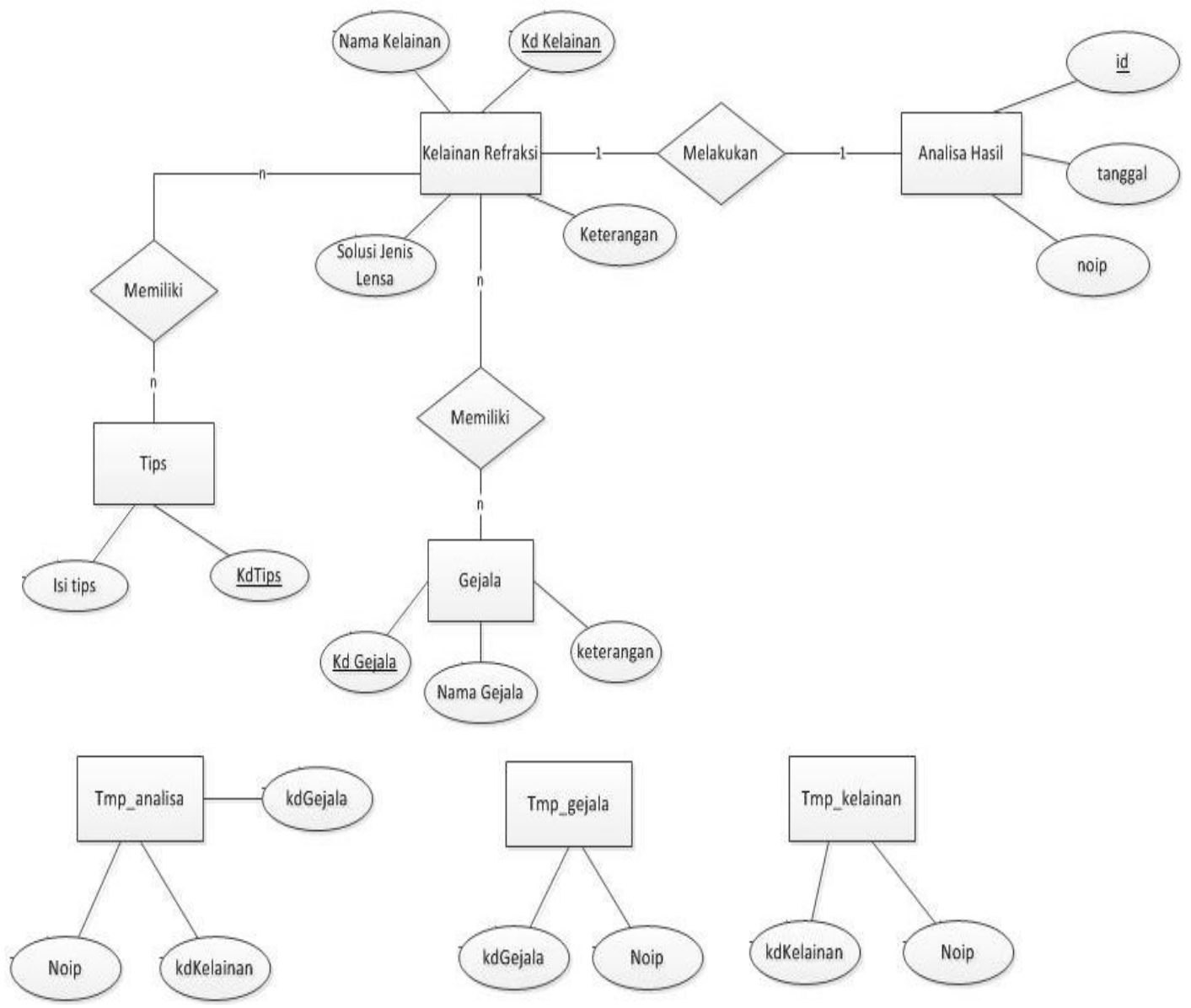

Gambar 5. Entity Relationship Diagram

\section{G. Tampilan Antarmuka}

Berikut merupakan tampilan antarmuka aplikasi diagnosis kelainan refraksi pada mata dan tips perawatan mata dengan metode forward chaining berbasis web (studi kasus Rosya Optikal).

1. Tampilan Antarmuka Menu Beranda Pada Gambar 6 ditunjukkan tampilan antarmuka menu beranda. Terdapat menu Daftar Kelainan Refraksi, Pemeriksaan dan Masuk Pakar (khusus penglola aplikasi).

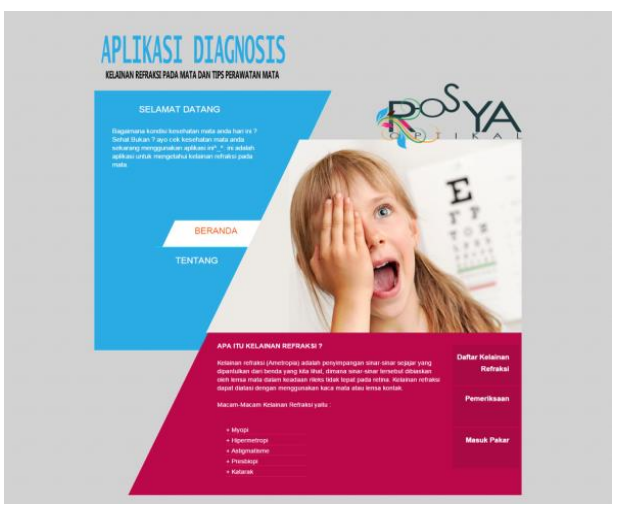

Gambar 6. Menu Beranda
2. Tampilan Antarmuka Menu Daftar Kelainan Pada Gambar 7 ditunjukkan tampilan antarmuka menu Daftar Kelainan Refraksi beserta penjelasannya masing-masing.

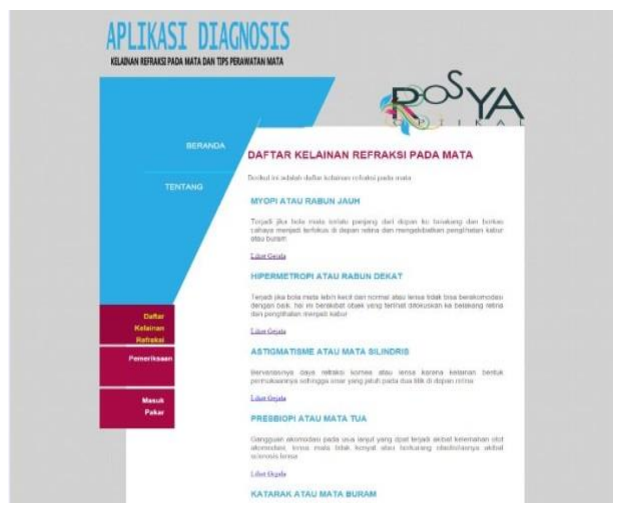

Gambar 7. Menu Daftar Kelainan

3. Tampilan Antarmuka Menu Pemeriksaan Pada Gambar 8 ditunjukkan tampilan antarmuka menu pemeriksaan. Layar akan menyajikan beberapa pertanyaan untuk dijawab oleh pengguna untuk mendeteksi kelainan refraksi jenis aplakah yang dialami oleh mata pengguna. 


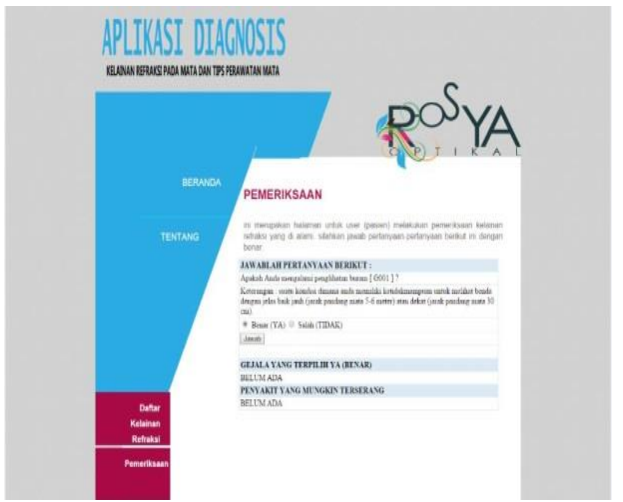

Gambar 8. Menu Pemeriksaan

Setelah melakukan pemeriksaan pasien akan mengetahui analisa hasil kelainan refraksi yang dialami. Pada Gambar 9 ditunjukkan tampilan antarmuka analisa hasil pemeriksaan menggunakan Metode Forward Chaining.

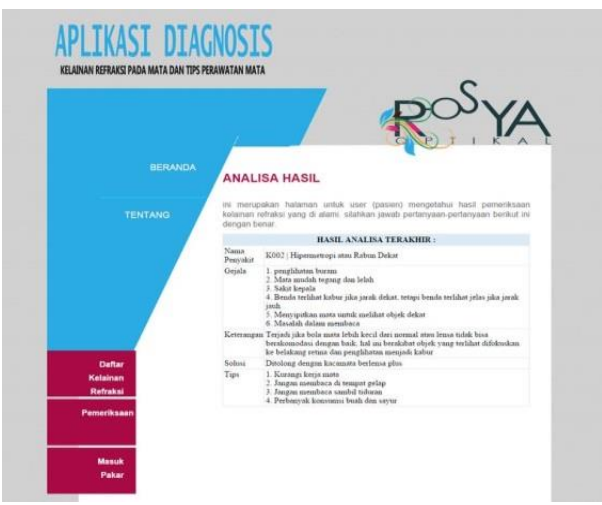

Gambar 9. Analisa Hasil

4. Tampilan Antarmuka Menu Pakar

Pada Gambar 10 ditunjukkan tampilan antarmuka halaman pakar untuk mengelola aturan pada Metode Forward Chaining sesuai jenis kelainan refraksi.

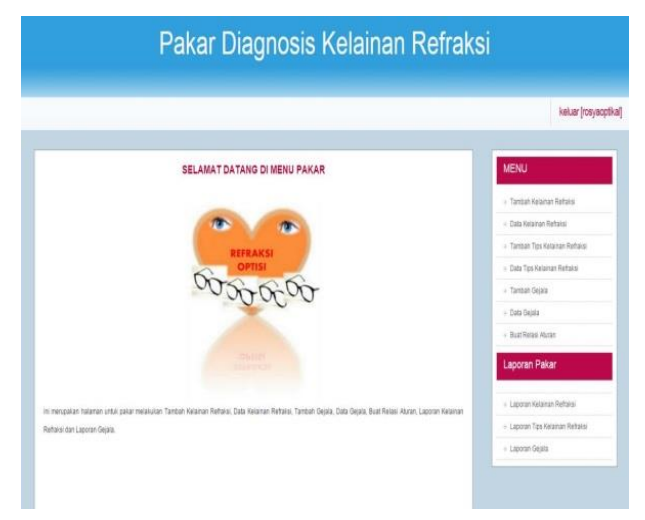

Gambar 10. Menu Pakar

5. Tampilan Antarmuka Menu Buat Relasi

Pada Gambar 11 ditunjukkan tampilan antarmuka untuk melihat relasi aturan yang telah tersedia.

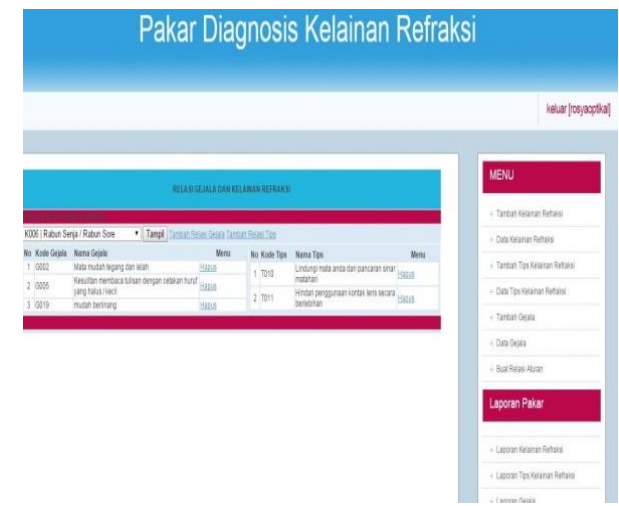

Gambar 11. Menu Lihat Relasi Aturan

6. Tampilan Antarmuka Menu Laporan Pada Gambar 12 ditunjukkan tampilan antarmuka laporan-laporan pada aplikasi diagnosis kelainan refraksi pada mata.

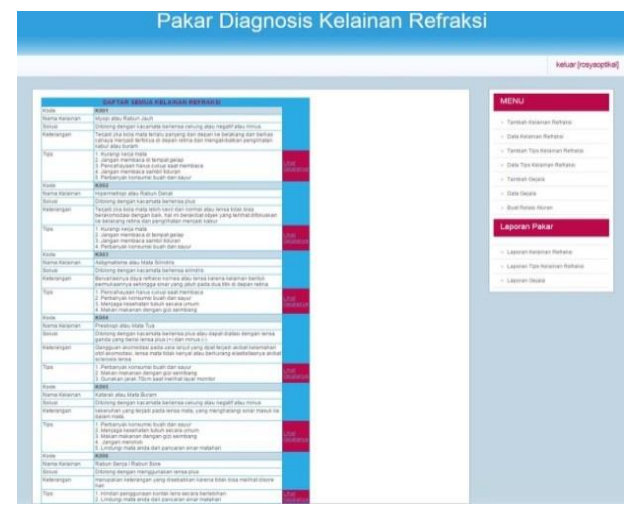

Gambar 12. Laporan Kelainan Nrefraksi

Pada Gambar 13 ditunjukkan tampilan antarmuka laporan tips kelainan refraksi.

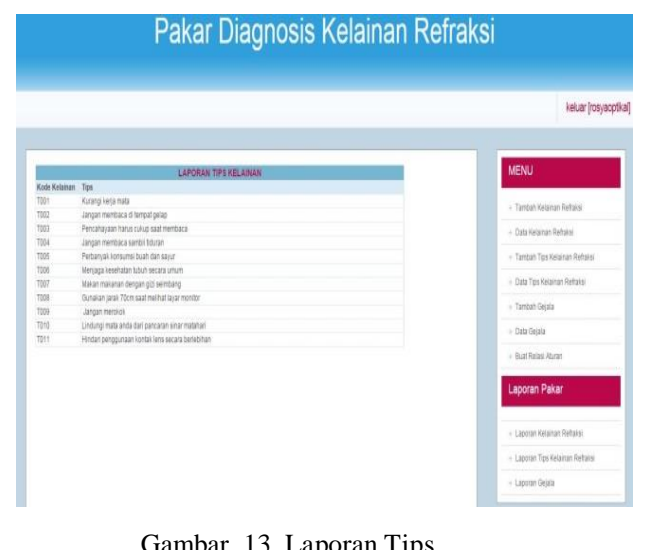

Pada Gambar 14 ditunjukkan tampilan antarmuka laporan gejala kelainan refraksi. 


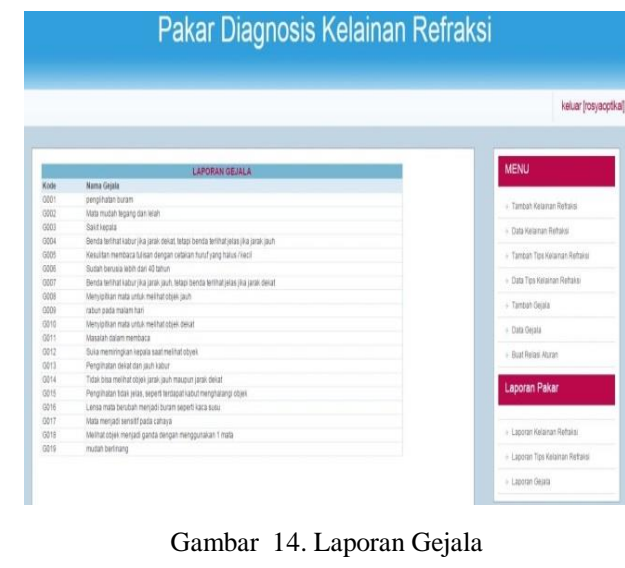

V. PENUTUP

\section{A. Kesimpulan}

Berdasarkan hasil dari analisis, pembangunan dan pengujian aplikasi diagnosis kelainan refraksi dan tips perawatan mata dengan metode forward chaining ini, maka dapat disimpulkan sebagai berikut.

1. Aplikasi ini dapat melakukan pemeriksaan kelainan refraksi.plikasi ini dapat mendiagnosis dan mengetahui hasil diagnosis kelainan refraksi pada mata pasien dengan menggunakan metode forward chaining, metode forward chaining yang diterapkan pada aplikasi adalah berupa pembuatan relasi aturan dengan memilih gejala-gejala dan tips kelainan refraksi sesuai kelainan refraksi, penginputan gejala dan tips dilakukan secara satu persatu sesuai kelainan refraksinya .

2. Aplikasi ini dapat mengetahui tips perawatan mata yang sesuai dengan kelainan mata yang dialami pasien.

3. Aplikasi ini dapat mengetahui solusi jenis lensa yang sesuai dengan kelainan mata yang dialami pasien.

\section{B. Saran}

Dalam pembangunan aplikasi diagnosis kelainan refraksi dan tips perawatan mata dengan metode forward chaining, diperlukan juga sebuah pengembangan perangkat lunak lebih lanjut diharapkan dapat.

1. Aplikasi yang dapat menangani pembuatan relasi aturan dengan banyak data sekaligus sehingga pembuatan relasi aturan kelainan refraksi menjadi lebih cepat.

2. Aplikasi yang dapat mengelola laporan rekam medis pasien.

3. Melakukan pengujian Turing Test untuk membandingkan hasil diagnosis dari aplikasi dengan diagnosis dari dokter yang sebenarnya.

\section{DAFTAR PUSTAKA}

[1] Roger S. Pressman, Ph.D., REKAYASA PERANGKAT LUNAK Pendekatan Praktisi (Buku I). Yogyakarta: ANDI dan McGraw-Hill Book Co., 2012.

[2] M Shalahuddin Rosa A S, Rekayasa Perangkat Lunak Terstruktur dan Berorientasi Objek. Bandung: Informatika, 2013.

[3] Achmad Afifudin, Noor Syamsu dan Rahasiah Taufik Anastasia Vanny Launardo, "TALLO, KELAINAN REFRAKSI PADA ANAK USIA 3 - 6 TAHUN DI KECAMATAN," 2010.

[4] Anton Setiawan Honggowibowo, "Sistem Pakar Diagnosa Penyakit Tanaman Padi Berbasis Web dengan Forward Chaining dan Backward Chaining," Telkomnika, vol. Vol 7, 2009.

[5] Bunafit Nugroho, Aplikasi Sistem Pakar dengan PHP \& Editor Dreamweaver. Yogyakarta: Gava Media, 2014.

[6] Erny Untari, "DIAGNOSIS KESULITAN BELAJAR POKOK BAHASAN PECAHAN," Jurnal Ilmiah STKIP PGRI Ngawi, vol. vol 13 no 1, 2014.

[7] Bunafit Nugroho, PHP dan Mysql dengan Editor Dreamweaver MX. Yogyakarta: ANDI, 2004.

[8] Kasiman Peranginangin, Aplikasi Web dengan PHP dan MySQL. Yogyakarta: ANDI, 2006.

[9] M Shalahuddin Rosa A S, Modul Pembelajaran Rekayasa Perangkat Lunak. Bandung: Modula, 2011.

[10] PT Elex Media Kommutindo, Pemrograman Web Aplikatif dengan Java. Jakarta: PT Elex Media Kommutindo, 2011.

[11] Sharive, Proyek Membangun Website dengan YII. Yogyakarta: Lokomedia,2014. 
ISSN : 2085-3688; e-ISSN : 2460-0997

Aplikasi Diagnosis Kelainan Refraksi Mata dan Tips Perawatan Mata dengan Metode Forward Chaining Berbasis Web 